Julie Bakken Jepsen, Goedele De Clerck, Sam Lutalo-Kiingi, William B. McGregor (Eds.)

Sign Languages of the World 



\section{Sign Languages of the World}

A Comparative Handbook

Edited by

Julie Bakken Jepsen, Goedele De Clerck, Sam Lutalo-Kiingi, William B. McGregor 
ISBN 978-1-61451-796-2

e-ISBN (PDF) 978-1-61451-817-4

e-ISBN (EPUB) 978-1-5015-0102-9

Library of Congress Cataloging-in-Publication Data

A CIP catalog record for this book has been applied for at the Library of Congress.

Bibliographic information published by the Deutsche Nationalbibliothek The Deutsche Nationalbibliothek lists this publication in the Deutsche Nationalbibliografie; detailed bibliographic data are available on the Internet at http://dnb.dnb.de.

(C) 2015 Walter de Gruyter, Inc., Berlin/Boston and Ishara Press, Preston, UK Cover image: Juan Ramón Valiño Typesetting: Meta Systems Publishing \& Printservices GmbH, Wustermark Printing and binding: CPI books $\mathrm{GmbH}$, Leck (2) Printed on acid-free paper Printed in Germany

www.degruyter.com 